\title{
PKA and PKC are required for long-term but not short-term in vivo operant memory in Aplysia
}

\author{
Maximilian Michel, Charity L. Green, and Lisa C. Lyons ${ }^{1}$ \\ Program in Neuroscience, Department of Biological Science, Florida State University, Tallahassee, Florida 32306-4295, USA
}

\begin{abstract}
We investigated the involvement of PKA and PKC signaling in a negatively reinforced operant learning paradigm in Aplysia, learning that food is inedible (LFI). In vivo injection of PKA or PKC inhibitors blocked long-term LFI memory formation. Moreover, a persistent phase of PKA activity, although not PKC activity, was necessary for long-term memory. Surprisingly, neither PKA nor PKC activity was required for associative short-term LFI memory. Additionally, PKA and PKC were not required for the retrieval of short- or long-term memory (STM and LTM, respectively). These studies have identified key differences between the mechanisms underlying nonassociative sensitization, operant reward learning, and LFI memory in Aplysia.
\end{abstract}

[Supplemental material is available for this article.]

Signaling cascades and the mechanisms underlying memory appear highly conserved across phylogeny with similar mechanisms identified in vertebrates and invertebrates (Sweatt 2003). Studies using the marine mollusk Aplysia have been critical in providing fundamental knowledge regarding the molecular basis of memory (for review, see Bailey et al. 2008). The cAMP-PKA signaling pathway represents a classical pathway necessary for many types of memory and synaptic plasticity, including presynaptic facilitation in Aplysia (for review, see Kandel 2001), olfactory conditioning in Drosophila (for review, see Davis 2005), long-term associative memory in mammals (for review, see Selcher et al. 2002), and late long-term potentiation (LTP) (Abel et al. 1997; Huang et al. 2000). Similarly, PKC signal transduction has been shown as integral for memory in Aplysia (Sacktor et al. 1988; Sugita et al. 1992; Sossin et al. 1994; Manseau et al. 1998), LTP (for review, see MacDonald et al. 2001; Sacktor 2008), and contextual fear conditioning (Atkins et al. 1998). Considerable intersection exists between the PKA and PKC signaling pathways during memory formation (Sugita et al. 1997; Lorenzetti et al. 2008). Despite the extensive research in Aplysia, few studies have been done on signaling in vivo due to limitations in genetic tractability and available species-specific reagents. In the present research, we have compared the roles of PKA and PKC between short-term memory (STM) and long-term memory (LTM) using in vivo behavioral studies.

We examined the role of PKA and PKC using the operant conditioning paradigm, learning that food is inedible (LFI). In this paradigm, animals associate a netted seaweed with the failure to swallow resulting in memory that the food is inedible. As previously described (Lyons et al. 2005, 2006), Aplysia californica were fed to satiation with laver seaweed $5 \mathrm{~d}$ prior to an experiment. Individual animals were trained using netted seaweed to which animals responded with repeated cycles of biting, swallowing attempts, and rejection of the food. Memory depends upon swallowing attempts followed by signaling from the gut denoting the failure of feeding (Schwarz and Susswein 1986; Schwarz et al. 1991). Presentation of the netted seaweed continued until the

'Corresponding author.

E-mail lyons@bio.fsu.edu; fax (850) 645-8447.

Article is online at http://www.learnmem.org/cgi/doi/10.1101/lm.2026311. animal rejected the food for $3 \mathrm{~min}$ without re-entry into the mouth. Upon testing, memory was measured as a significant reduction in the total response time and the time seaweed was retained in the mouth compared to initial training. A single training session results in associative LTM specific for the seaweed used during training (Susswein et al. 1986). To confirm that $30 \mathrm{~min}$ STM also represents a specific association with the seaweed from training, we trained one set of animals with laver and a second set with kombu seaweed. During testing, half the animals were tested with the seaweed from training while the other half was tested with the alternate seaweed. STM was observed only in animals for which the same seaweed was used for training and testing (Supplemental Fig. 1). Animals in which testing occurred using the alternate seaweed exhibited responses similar to training times. As with LTM, short-term LFI memory represents specific learned associations rather than a broader decrement in feeding responses. Since STM and LTM are also temporally distinct (Botzer et al. 1998), the LFI paradigm provides the opportunity to distinguish between signaling pathways recruited for LTM and those necessary for STM.

In Aplysia, PKA is necessary for multiple types of LTM including sensitization, classical conditioning, and operant learning (for review, see Baxter and Byrne 2006; Bailey et al. 2008). To investigate the role of PKA in operant memory in vivo, animals were injected $30 \mathrm{~min}$ before training with vehicle (ASW) or $1 \mathrm{~mL} /$ $100 \mathrm{~g}$ body weight of $19.5 \mu \mathrm{M}$ H89 (Sigma), a PKA inhibitor previously used in Aplysia (Farah et al. 2009) that binds to the catalytic subunit (Hidaka et al. 1984, 1990). This yielded a predicted 300-nM H89 systemic concentration estimated based on hemolymph representing $65 \%$ of body weight (Levenson et al. 1999). In all experiments, animals were trained at Zeitgeber time 3 to eliminate circadian variance. No significant difference was observed in training responses between vehicle-injected and inhibitor-treated animals (Supplemental Fig. 2A,B). Upon testing $24 \mathrm{~h}$ later, vehicle-injected animals demonstrated robust memory with significantly reduced response times, while animals treated with H89 exhibited no LTM (Fig. 1A). Similar results were observed for a second parameter used to assess memory, the time the seaweed was retained in the mouth (Supplemental Fig. 3). These results suggest that LTM requires PKA activity. However, H89 has been reported to exhibit broader effects on 
A
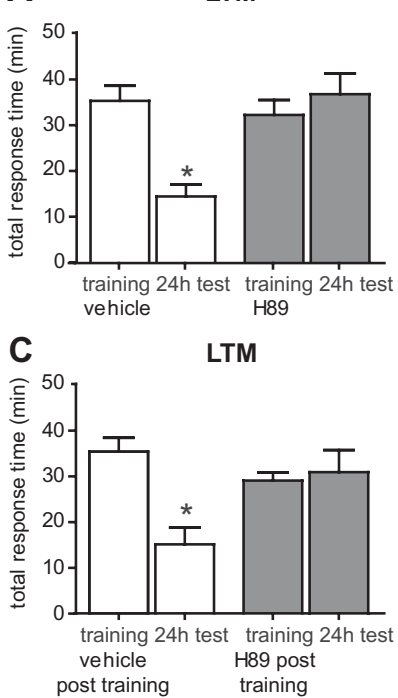

post training training

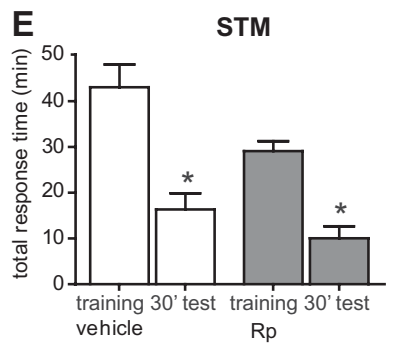

Figure 1. Prolonged PKA activity is necessary for long-term (LTM) but not short-term memory (STM). (A) Inhibition of PKA with 300-nM H89 30 min before training prevented LTM. Vehicle-injected animals displayed significantly decreased response times (control $n=14$, H89 $n=15$; $\left.F_{(3,57)}=8.389, P<0.001\right)$. Mean and SEM are plotted. (B) Rp-cAMPS injected before training blocked LTM (control $n=5$, Rp-cAMPS $n=6$; $\left.F_{(3,21)}=6.335 ; P<0.05\right)$. (C) Prolonged PKA is required for LTM. H89 injected $5 \mathrm{~min}$ after training inhibited LTM, while vehicle-injected animals exhibited significant LTM (control $n=9, \mathrm{H} 89 n=8 ; F_{(3,33)}=$ 6.588, $P<0.01)$. $(D) \mathrm{H} 89$ had no effect on STM formation as both control and drug-treated animals demonstrated significant STM (control $\left.n=14, \mathrm{H} 89 n=12 ; F_{(3,51)}=34.56, P<0.001\right)$. (E) Injection of $10 \mu \mathrm{M}$ Rp-cAMPS did not block STM (control $n=5$, Rp-cAMPS $n=6 ; F_{(3,21)}=$ 18.97, $P<0.001)$. Data analysis was performed using ANOVA followed by Bonferroni's multiple comparison test (MCT). Asterisks denote significant differences with $P<0.05$ for the testing vs. training groups. White bars represent mean response times for vehicle-treated animals, while gray bars signify mean response times for drug-treated animals.

mitogen and stress-activated protein kinase 1, Rho-dependent protein kinase II, and p70 ribosomal protein S6 kinase (Davies et al. 2000). Potentially, interference with one of these kinases could result in inhibition of LFI memory as all have been at least peripherally implicated in memory in other paradigms (Udo et al. 2005; Chwang et al. 2007; Sindreu et al. 2007).

To independently test the role of PKA, we used Rp-cAMPS, a phosphodiesterase resistant competitive inhibitor (de Wit et al. 1982; Rothermel et al. 1983) previously used in Aplysia (Ghirardi et al. 1992; Dyer and Sossin 2000; Lorenzetti et al. 2008). Injections of $1 \mathrm{~mL} / 100 \mathrm{~g}$ of $650 \mu \mathrm{M}$ Rp-cAMPS (Sigma; predicted systemic concentration $10 \mu \mathrm{M}) 30 \mathrm{~min}$ before training significantly inhibited LTM compared to vehicle-injected animals (Fig. 1B; Supplemental Fig. 3B). This lack of LTM upon treatment with either Rp-cAMPS or H89 prior to training strongly suggests a requirement for PKA.
It remained possible that the long responses observed during testing were due to persistent effects of the drugs in vivo that affected feeding behavior through a mechanism independent of LTM. To test this possibility, animals were injected with vehicle, H89, or Rp-cAMPS and tested $24 \mathrm{~h}$ later. No significant differences in response times were found between vehicle and inhibitorinjected animals indicating that the inhibitors alone do not result in increased appetitive or consummatory behavioral responses (Total Time [min]: controls $37.8 \pm 3.3[n=11]$, H89 $32.0 \pm 3.0$ $[n=6]$, Rp-cAMPs $30.0 \pm 6.0[n=6]$, ANOVA $P=0.35$; Time in the Mouth [min]: controls $36.8 \pm 3.1$; H89 29.1 \pm 3.0; Rp-cAMPs $25.9 \pm 6.0$, ANOVA $P=0.14$ ).

In many forms of learning, PKA activation is necessary for the induction of LTM and the molecular consolidation of memory (Bailey et al. 2008). During long-term facilitation, a prolonged requirement for PKA activity lasting several hours appears necessary for LTM (Müller and Carew 1998). To determine whether long-term LFI required persistent PKA activity, we injected animals with H89 5 min after training targeting a time when the
A
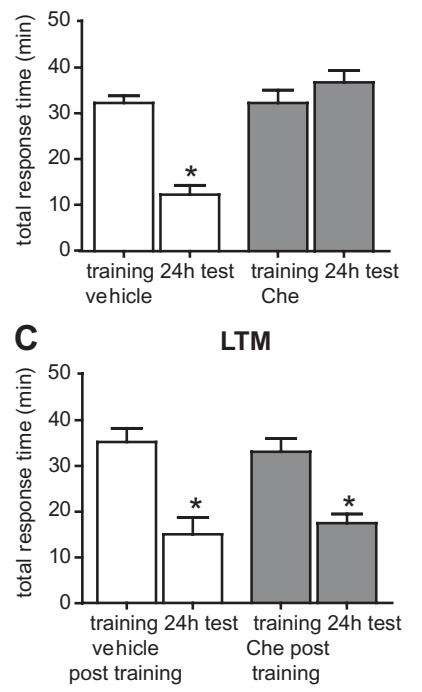

E

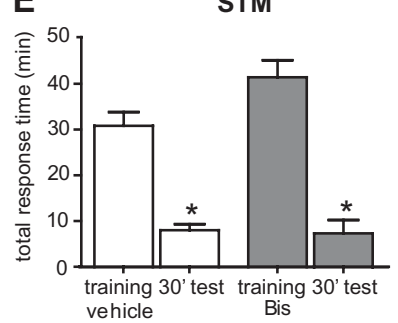

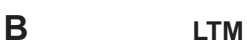
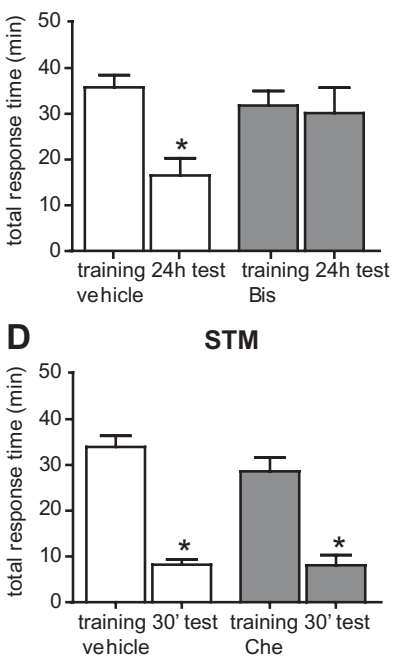

Figure 2. PKC is required for the induction of LTM but not STM. $(A)$ Inhibition of PKC before training with chelerythrine inhibited LTM. Vehicle-injected animals exhibited robust memory with significantly decreased response times (control $n=15$, chelerythrine $n=15$; $\left.F_{(3,59)}=22.66 ; P<0.001\right)$. $(B)$ Bisindolylmaleimide I (control $n=14$, bis $\left.n=13 ; F_{(3,53)}=4.738 ; P<0.01\right)$ treatment before training also blocked LTM. (C) Inhibition of PKC with chelerythrine after training had no effect on LTM (control $n=9$, chelerythrine $n=8 ; F_{(3,33)}=12.14$, $P<0.001)$. (D) The PKC inhibitor chelerythrine had no effect on STM formation as treated animals displayed robust STM comparable to controls (control $n=13$, chelerythrine $\left.n=10 ; F_{(3,45)}=37.86, P<0.001\right)$. (E) Bisindolylmaleimide I failed to inhibit STM formation (control $n=7$, bis $\left.n=8 ; F_{(3,29)}=33.78 ; P<0.001\right)$. Data analysis was performed using ANOVA followed by Bonferroni's MCT. Asterisks denote significant differences with $P<0.05$ for the testing vs. training groups. 
A

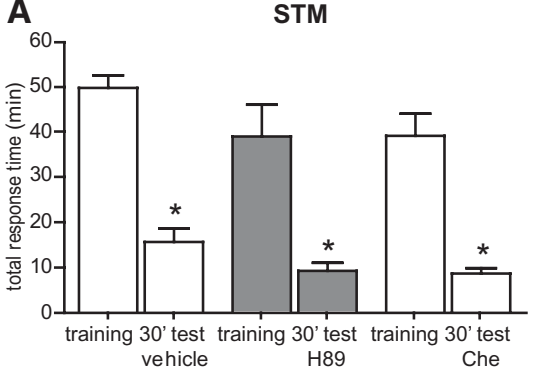

B

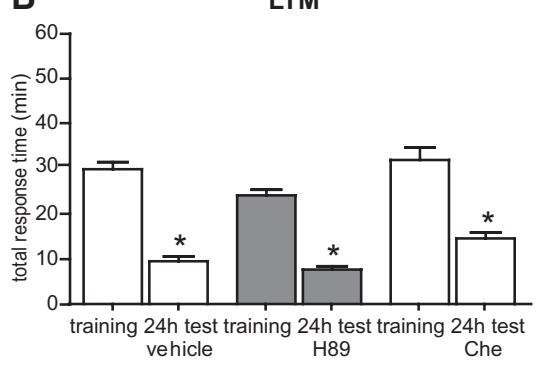

Figure 3. $P K A$ and $P K C$ are not required for the recall of memory. $(A)$ Animals were injected with either vehicle (ASW), H89, or chelerythrine immediately after training and then tested for STM 30 min later. Neither the inhibitor for PKA nor the inhibitor of PKC blocked the expression or retrieval of STM with all groups exhibiting comparable significant STM $\left(n=6\right.$ for each group; $\left.F_{(5,35)}=20.07 ; P<0.001\right)$. (B) Animals were trained and $24 \mathrm{~h}$ later injected with either vehicle (ASW), $\mathrm{H} 89$, or chelerythrine $30 \mathrm{~min}$ prior to testing. Neither the inhibitor for PKA nor the inhibitor of PKC blocked the recall of LTM with all groups exhibiting comparable significant LTM $(n=9,8,9$, respectively; $\left.F_{(5,51)}=40.86 ; P<0.001\right)$. Data analysis was performed using ANOVA followed by Bonferroni's MCT. Asterisks denote significant differences with $P<0.05$ for the testing vs. training groups.

induction of memory had already been initiated (Botzer et al. 1998). Control animals exhibited robust LTM, while animals treated with H89 after training demonstrated no LTM with response times similar to training times (Fig. 1C). This requirement for prolonged PKA in LFI is consistent with previous research as PKA performs a vital role in the activation of CREBinduced transcription (for review, see Hawkins et al. 2006; Bailey et al. 2008).

In Aplysia, PKA appears necessary for most short-term plasticity including facilitation (Byrne and Kandel 1996), associative plasticity (Ocorr et al. 1985; Abrams et al. 1998), and in vitro operant reward learning (Lorenzetti et al. 2008). However, when a broader spectrum of paradigms is examined across species, the role of PKA in STM appears more variable. PKA is required for LTM but not STM in fear conditioning (Abel et al. 1997; Goosens et al. 2000; Schafe and LeDoux 2000) and conditioned taste aversion (Koh et al. 2002). As many of the studies establishing PKA in STM in Aplysia occurred in vitro, we investigated PKA in short-term LFI. Animals were injected with vehicle or inhibitor $30 \mathrm{~min}$ before training and tested for STM $30 \mathrm{~min}$ later. Surprisingly, H89 had no effect on STM as treated animals displayed significant memory similar to controls (Fig. 1D; Supplemental Fig. 3D). Potentially, the lack of H89 effect was concentration dependent, although the dosage was sufficient to block LTM and exceeded the reported $\mathrm{IC}_{50}$ (Davies et al. 2000). To further probe the cAMP-PKA pathway in STM, we performed experiments with Rp-cAMPs as described above. Injection of Rp-cAMPS had no effect on STM as treated animals displayed significant memory comparable to controls (Fig. 1E). To verify that results were not due to inhibitor-induced decreases in feeding responses, we assessed the effect of H89 and Rp-cAMPs 90 min after injection. Inhibitors alone did not significantly affect response times (Total Response Time [min]: controls $29.6 \pm 3.2$ [ $n=17]$, H89 $24.6 \pm 3.0[n=7]$, Rp-cAMPs $28.5 \pm 4.5[n=4]$, ANOVA $P=$ 0.64; Time in Mouth [min]: controls $26.0 \pm 3.6$; H89 $21.7 \pm 3.1$; Rp-cAMPs $25.0 \pm 3.4$, ANOVA $P=0.76$ ). In contrast to short-term facilitation and neuronal excitability, these results strongly suggest that PKA is not necessary for induction or formation of shortterm LFI memory.

For the in vitro analog of operant reward learning, a calciummediated increase in PKC activity is proposed to modulate the PKA cascade (Baxter and Byrne 2006; Lorenzetti et al. 2008), suggesting the potential of PKC involvement in negatively reinforced operant memory. PKC also has been implicated in long-term facilitation (Sossin et al. 1994; Manseau et al. 1998) and activitydependent facilitation (Hu et al. 2007). To test the involvement of PKC in long-term LFI, animals were injected with the PKC inhibitor chelerythrine, which inhibits all classes of PKC (Herbert et al. 1990; Sossin 2007) and was previously used in many Aplysia studies (Khabour et al. 2004; Bougie et al. 2009; Villareal et al. 2009). We injected vehicle (ASW) or $1 \mathrm{~mL} / 100 \mathrm{~g}$ of $43.55 \mu \mathrm{M}$ chelerythrine (Calbiochem; $670 \mathrm{nM}$ predicted systemic concentration) $30 \mathrm{~min}$ before training and tested animals $24 \mathrm{~h}$ later. Inhibition of PKC with chelerythrine abolished LTM, while vehicle-injected animals exhibited robust memory (Fig. 2A). Similar results were observed for the time the food was retained in the mouth (Supplemental Fig. 4). Chelerythrine inhibits PKC via the catalytic domain (Herbert et al. 1990), so we investigated LTM using an inhibitor with a different mechanism of action, Bisindolylmaleimide I (Bis, Calbiochem), which acts at the ATP binding site (Toullec et al. 1991) and also was previously used in Aplysia (Kabir et al. 2001; Lim and Sossin 2006; Villareal et al. 2009). Injection of animals with $130 \mu \mathrm{L} / 100 \mathrm{~g} 5 \mathrm{mM}$ Bis (10 $\mu \mathrm{M}$ predicted systemic concentration) $30 \mathrm{~min}$ prior to training completely blocked LTM, while control animals injected with DMSO demonstrated significant LTM (Fig. 2B). Neither PKC inhibitor significantly affected the responses of the animals during training (Supplemental Fig. 2C,D). While chelerythrine broadly inhibits PKC, the inhibition of LTM by Bis implicates either classical or novel PKC since the atypical isoform is not inhibited by Bis (Sossin 2007; Villareal et al. 2009). To determine if the inhibitors alone impacted response times $24 \mathrm{~h}$ after treatment, animals were injected with the vehicle, chelerythrine, or Bis and tested $24 \mathrm{~h}$ later. There was no significant difference between the responses of vehicle- or inhibitor-injected animals (Total Response Time [min]: controls $37.8 \pm 3.3$ [ $n=11]$, chelerythrine $29.1 \pm 4.8[n=6]$, Bis $37.5 \pm 7.0[n=6]$, ANOVA $P=$ 0.39 ; Time in the Mouth [min]: controls $36.8 \pm 3.1$; chelerythrine $26.6 \pm 5.4$; Bis $32.5 \pm 7.2$, ANOVA $P=0.34$ ).

Persistent PKC activation is necessary for the maintenance of LTP (Klann et al. 1991; Sacktor et al. 1993) and for maintenance of long-term memory in rats (Jerusalinsky et al. 1994; Shema et al. 2007; Serrano et al. 2008). In Aplysia, persistently active PKC is involved in long-term facilitation (Sossin et al. 1994). Persistent, autonomous forms of PKC arise by proteolytic cleavage of the regulatory domain forming PKM (Inoue et al. 1977; Sutton et al. 2004; Bougie et al. 2009), an isoform inhibited by chelerythrine (Sossin 2007; Villareal et al. 2009). To test the requirement for persistent PKC in long-term LFI, we trained animals and injected them with chelerythrine after training. Contrary to the results we observed with inhibition of PKA, post-training PKC inhibitor injection did not block LTM (Fig. 2C). Thus, we hypothesize that the role for PKC in this form of operant LTM may be upstream of cAMP-PKA signaling and enhance PKA activation as proposed for operant reward learning (Baxter and Byrne 2006; Lorenzetti et al. 2008). 
In Aplysia, PKC has been implicated in short-term plasticity (Braha et al. 1990; Sacktor and Schwartz 1990; Sugita et al. 1992; for review, see Hawkins et al. 2006; Sossin 2007). We tested the role of PKC in STM using both chelerythrine and Bis as above. Neither chelerythrine nor Bis affected STM as treated and control groups exhibited robust memory (Fig. 2D,E), strongly suggesting that PKC activity is not required for short-term LFI. Inhibitors alone did not significantly affect responses 90 min after injection (Total Response Time [min]: controls $29.6 \pm 3.2[n=17]$, chelerythrine $40.0 \pm 7.5[n=6]$, Bis $25.5 \pm 2.6[n=6]$, ANOVA $P=$ 0.17 ; Time in the Mouth [min]: controls $26.0 \pm 3.6$; chelerythrine $38.1 \pm 7.9$; Bis $22.3 \pm 3.2$, ANOVA $P=0.16$ ). Although it may seem surprising that neither PKA nor PKC are required for shortterm LFI memory as these kinases appear prominent in Aplysia in vitro paradigms, our experiments do not preclude the activation of these kinases with training or even a modulatory role of these kinases in STM. As the same LFI training paradigm induces STM and LTM, our experiments demonstrate that while training may broadly induce the activation of many kinase and signaling pathways, only the activation of a subset of pathways is critical for STM in vivo.

Memory depends not only upon factors involved in induction and consolidation, but also those components necessary for maintenance and recall. To more fully understand the role of PKA and PKC in LFI memory, we tested whether these pathways were necessary for the expression or retrieval of memory. To evaluate STM, animals were trained and injected immediately after training with either $\mathrm{H} 89$ to inhibit PKA or chelerythrine to inhibit PKC. Animals were then tested for STM 30 min later. Neither PKA nor PKC appeared necessary for the maintenance or recall of short-term LFI as treated animals displayed STM comparable to controls (Fig. 3A; Supplemental Fig. 5). We performed similar experiments to test the recall of LTM. Animals were trained and then injected with H89, chelerythrine, or vehicle 30 min prior to testing (Fig. 3B). All groups exhibited significant LTM suggesting that neither PKA nor PKC is involved in the maintenance of memory at this late stage or necessary for recall of the memory.

During LFI training, nitric oxide and histamine signal failed swallowing attempts (Katzoff et al. 2002, 2006, 2010). For shortterm plasticity, NO-cGMP signaling may potentially modulate cyclic nucleotide gated calcium channels. During LTM formation, the recruitment of additional kinase pathways occurs followed by the requirement for polyADP-ribosylation (Cohen-Armon et al. 2004) and induction of the transcription factor CCAAT/enhancer binding protein (ApC/EBP) (Levitan et al. 2008). NO-cGMP signaling could activate the cAMP-PKA pathway for long-term LFI as proposed for LTM in honeybees and crickets (Müller 2000; Matsumoto et al. 2006, 2009). Furthermore, we hypothesize that PKC functions early during LTM with subsequent persistent PKA activation, CREB-dependent transcription and induction of $A p C / E B P$. Thus, the identification of mechanistic differences in the requirement for PKA and PKC between short- and long-term negatively reinforced operant memory highlights the complexity of signaling cascades underlying memory in a relatively simple model system.

\section{Acknowledgment}

This research was supported by National Institute of Mental Health grant no. 5R01MH81012 to L.C.L.

\section{References}

Abel T, Nguyen PV, Barad M, Deuel TA, Kandel ER, Bourtchouladze R. 1997. Genetic demonstration of a role for PKA in the late phase of LTP and in hippocampus-based long-term memory. Cell 88: 615-626.
Abrams TW, Yovell Y, Onyike CU, Cohen JE, Jarrard HE. 1998. Analysis of sequence-dependent interactions between transient calcium and transmitter stimuli in activating adenylyl cyclase in Aplysia: Possible contribution to CS-US sequence requirement during conditioning. Learn Mem 4: 496-509.

Atkins CM, Selcher JC, Petraitis JJ, Trzaskos JM, Sweatt JD. 1998. The MAPK cascade is required for mammalian associative learning. Nat Neurosci 1: 602-609.

Bailey CH, Barco A, Hawkins RD, Kandel ER, Byrne JH. 2008. Molecular studies of learning and memory in Aplysia and the hippocampus: A comparative analysis of implicit and explicit memory storage. In Learning and memory: A comprehensive reference (ed. JH Byrne), pp. 11-29. Academic, Oxford, UK.

Baxter DA, Byrne JH. 2006. Feeding behavior of Aplysia: A model system for comparing cellular mechanisms of classical and operant conditioning. Learn Mem 13: 669-680.

Botzer D, Markovich S, Susswein AJ. 1998. Multiple memory processes following training that a food is inedible in Aplysia. Learn Mem 5: $204-219$.

Bougie JK, Lim T, Farah CA, Manjunath V, Nagakura I, Ferraro GB, Sossin WS. 2009. The atypical protein kinase C in Aplysia can form a protein kinase M by cleavage. J Neurochem 109: 1129-1143.

Braha O, Dale N, Hochner B, Klein M, Abrams TW, Kandel ER. 1990. Second messengers involved in the two processes of presynaptic facilitation that contribute to sensitization and dishabituation in Aplysia sensory neurons. Proc Natl Acad Sci 87: 2040-2044.

Byrne JH, Kandel ER. 1996. Presynaptic facilitation revisited: State and time dependence. J Neurosci 16: 425-435.

Chwang WB, Arthur JS, Schumacher A, Sweatt JD. 2007. The nuclear kinase mitogen- and stress-activated protein kinase 1 regulates hippocampal chromatin remodeling in memory formation. J Neurosci 27: $12732-12742$.

Cohen-Armon M, Visochek L, Katzoff A, Levitan D, Susswein AJ, Klein R, Valbrun M, Schwartz JH. 2004. Long-term memory requires polyADP-ribosylation. Science 304: $1820-1822$.

Davies SP, Reddy H, Caivano M, Cohen P. 2000. Specificity and mechanism of action of some commonly used protein kinase inhibitors. Biochem J 351: $95-105$.

Davis RL. 2005. Olfactory memory formation in Drosophila: From molecular to systems neuroscience. Annu Rev Neurosci 28: 275-302.

de Wit RJ, Hoppe J, Stec WJ, Baraniak J, Jastorff B. 1982. Interaction of cAMP derivatives with the 'stable' cAMP-binding site in the cAMP-dependent protein kinase type I. Eur J Biochem 122: 95-99.

Dyer JR, Sossin WS. 2000. Regulation of eukaryotic initiation factor $4 \mathrm{E}$ phosphorylation in the nervous system of Aplysia californica. $J$ Neurochem 75: $872-881$.

Farah CA, Weatherill D, Dunn TW, Sossin WS. 2009. PKC differentially translocates during spaced and massed training in Aplysia. J Neurosci 29: $10281-10286$.

Ghirardi M, Braha O, Hochner B, Montarolo PG, Kandel ER, Dale N. 1992 Roles of PKA and PKC in facilitation of evoked and spontaneous transmitter release at depressed and nondepressed synapses in Aplysia sensory neurons. Neuron 9: 479-489.

Goosens KA, Holt W, Maren S. 2000. A role for amygdaloid PKA and PKC in the acquisition of long-term conditional fear memories in rats. Behav Brain Res 114: 145-152.

Hawkins RD, Kandel ER, Bailey CH. 2006. Molecular mechanisms of memory storage in Aplysia. Biol Bull 210: 174-191.

Herbert JM, Augereau JM, Gleye J, Maffrand JP. 1990. Chelerythrine is a potent and specific inhibitor of protein kinase C. Biochem Biophys Res Commun 172: 993-999.

Hidaka H, Inagaki M, Kawamoto S, Sasaki Y. 1984. Isoquinolinesulfonamides, novel and potent inhibitors of cyclic nucleotide dependent protein kinase and protein kinase C. Biochemistry 23: 5036-5041.

Hidaka H, Hagiwara M, Chijiwa T. 1990. Molecular pharmacology of protein kinases. Neurochem Res 15: 431-434.

Hu JY, Chen Y, Schacher S. 2007. Protein kinase C regulates local synthesis and secretion of a neuropeptide required for activity-dependent long-term synaptic plasticity. J Neurosci 27: 8927-8939.

Huang YY, Martin KC, Kandel ER. 2000. Both protein kinase A and mitogen-activated protein kinase are required in the amygdala for the macromolecular synthesis-dependent late phase of long-term potentiation. J Neurosci 20: 6317-6325.

Inoue M, Kishimoto A, Takai Y, Nishizuka Y. 1977. Studies on a cyclic nucleotide-independent protein kinase and its proenzyme in mammalian tissues. II. Proenzyme and its activation by calcium-dependent protease from rat brain. J Biol Chem 252: 7610-7616.

Jerusalinsky D, Quillfeldt JA, Walz R, Da Silva RC, Medina JH, Izquierdo I. 1994. Post-training intrahippocampal infusion of protein kinase $\mathrm{C}$ inhibitors causes amnesia in rats. Behav Neural Biol 61: 107-109. 
Kabir N, Schaefer AW, Nakhost A, Sossin WS, Forscher P. 2001. Protein kinase $C$ activation promotes microtubule advance in neuronal growth cones by increasing average microtubule growth lifetimes. J Cell Biol 152: $1033-1044$.

Kandel ER. 2001. The molecular biology of memory storage: A dialogue between genes and synapses. Science 294: 1030-1038.

Katzoff A, Ben-Gedalya T, Susswein AJ. 2002. Nitric oxide is necessary for multiple memory processes after learning that a food is inedible in Aplysia. J Neurosci 22: 9581-9594.

Katzoff A, Ben-Gedalya T, Hurwitz I, Miller N, Susswein YZ, Susswein AJ. 2006. Nitric oxide signals that Aplysia have attempted to eat, a necessary component of memory formation after learning that food is inedible. J Neurophysiol 96: 1247-1257.

Katzoff A, Miller N, Susswein AJ. 2010. Nitric oxide and histamine signal attempts to swallow: A component of learning that food is inedible in Aplysia. Learn Mem 17: 50-62.

Khabour O, Levenson J, Lyons LC, Kategaya LS, Chin J, Byrne JH, Eskin A. 2004. Coregulation of glutamate uptake and long-term sensitization in Aplysia. J Neurosci 24: 8829-8837.

Klann E, Chen SJ, Sweatt JD. 1991. Persistent protein kinase activation in the maintenance phase of long-term potentiation. J Biol Chem 266: 24253-24256.

Koh MT, Thiele TE, Bernstein IL. 2002. Inhibition of protein kinase A activity interferes with long-term, but not short-term, memory of conditioned taste aversions. Behav Neurosci 116: 1070-1074.

Levenson J, Byrne JH, Eskin A. 1999. Levels of serotonin in the hemolymph of Aplysia are modulated by light/dark cycles and sensitization training. I Neurosci 19: 8094-8103.

Levitan D, Lyons LC, Perelman A, Green CL, Motro B, Eskin A, Susswein AJ. 2008. Training with inedible food in Aplysia causes expression of C/EBP in the buccal but not cerebral ganglion. Learn Mem 15: $412-416$.

Lim T, Sossin WS. 2006. Phosphorylation at the hydrophobic site of protein kinase C Apl II is increased during intermediate term facilitation. Neuroscience 141: 277-285.

Lorenzetti FD, Baxter DA, Byrne JH. 2008. Molecular mechanisms underlying a cellular analog of operant reward learning. Neuron 59: $815-828$.

Lyons LC, Rawashdeh O, Katzoff A, Susswein AJ, Eskin A. 2005. Circadian modulation of complex learning in diurnal and nocturnal Aplysia. Proc Natl Acad Sci 102: 12589-12594.

Lyons LC, Rawashdeh O, Eskin A. 2006. Non-ocular circadian oscillators and photoreceptors modulate long-term memory formation in Aplysia. J Biol Rhythms 21: 245-255.

MacDonald JF, Kotecha SA, Lu WY, Jackson MF. 2001. Convergence of PKC-dependent kinase signal cascades on NMDA receptors. Curr Drug Targets 2: 299-312.

Manseau F, Sossin WS, Castellucci VF. 1998. Long-term changes in excitability induced by protein kinase $\mathrm{C}$ activation in Aplysia sensory neurons. I Neurophysiol 79: 1210-1218.

Matsumoto Y, Unoki S, Aonuma H, Mizunami M. 2006. Critical role of nitric oxide-cGMP cascade in the formation of cAMP-dependent long-term memory. Learn Mem 13: 35-44.

Matsumoto Y, Hatano A, Unoki S, Mizunami M. 2009. Stimulation of the cAMP system by the nitric oxide-cGMP system underlying the formation of long-term memory in an insect. Neurosci Lett 467: 81-85.

Müller U. 2000. Prolonged activation of cAMP-dependent protein kinase during conditioning induces long-term memory in honeybees. Neuron 27: $159-168$

Müller U, Carew TJ. 1998. Serotonin induces temporally and mechanistically distinct phases of persistent PKA activity in Aplysia sensory neurons. Neuron 21: 1423-1434.

Ocorr KA, Walters ET, Byrne JH. 1985. Associative conditioning analog selectively increases cAMP levels of tail sensory neurons in Aplysia. Proc Natl Acad Sci 82: 2548-2552.

Rothermel JD, Stec WJ, Baraniak J, Jastorff B, Botelho LH. 1983. Inhibition of glycogenolysis in isolated rat hepatocytes by the Rp diastereomer of adenosine cyclic 3',5'-phosphorothioate. J Biol Chem 258: $12125-12128$.
Sacktor TC. 2008. PKMzeta, LTP maintenance, and the dynamic molecular biology of memory storage. Prog Brain Res 169: 27-40.

Sacktor TC, Schwartz JH. 1990. Sensitizing stimuli cause translocation of protein kinase C in Aplysia sensory neurons. Proc Natl Acad Sci 87: 2036-2039.

Sacktor TC, Kruger KE, Schwartz JH. 1988. Activation of protein kinase C by serotonin: Biochemical evidence that it participates in the mechanisms underlying facilitation in Aplysia. J Physiol (Paris) 83: 224-231.

Sacktor TC, Osten P, Valsamis H, Jiang X, Naik MU, Sublette E. 1993. Persistent activation of the $\zeta$ isoform of protein kinase $\mathrm{C}$ in the maintenance of long-term potentiation. Proc Natl Acad Sci 90: 8342-8346.

Schafe GE, LeDoux JE. 2000. Memory consolidation of auditory pavlovian fear conditioning requires protein synthesis and protein kinase $\mathrm{A}$ in the amygdala. J Neurosci 20: RC96.

Schwarz M, Susswein AJ. 1986. Identification of the neural pathway for reinforcement of feeding when Aplysia learn that food is inedible. $J$ Neurosci 6: $1528-1536$.

Schwarz M, Feldman E, Susswein AJ. 1991. Variables affecting long-term memory of learning that a food is inedible in Aplysia. Behav Neurosci 105: $193-201$

Selcher JC, Weeber EJ, Varga AW, Sweatt JD, Swank M. 2002. Protein kinase signal transduction cascades in mammalian associative conditioning. Neuroscientist 8: 122-131.

Serrano P, Friedman EL, Kenney J, Taubenfeld SM, Zimmerman JM, Hanna J, Alberini C, Kelley AE, Maren S, Rudy JW, et al. 2008. PKM $\zeta$ maintains spatial, instrumental, and classically conditioned long-term memories. PLoS Biol 6: 2698-2706.

Shema R, Sacktor TC, Dudai Y. 2007. Rapid erasure of long-term memory associations in the cortex by an inhibitor of PKM $\zeta$. Science 317: 951-953.

Sindreu CB, Scheiner ZS, Storm DR. 2007. $\mathrm{Ca}^{2+}$-stimulated adenylyl cyclases regulate ERK-dependent activation of MSK1 during fear conditioning. Neuron 53: 79-89.

Sossin WS. 2007. Isoform specificity of protein kinase Cs in synaptic plasticity. Learn Mem 14: 236-246.

Sossin WS, Sacktor TC, Schwartz JH. 1994. Persistent activation of protein kinase C during the development of long-term facilitation in Aplysia. Learn Mem 1: 189-202.

Sugita S, Goldsmith JR, Baxter DA, Byrne JH. 1992. Involvement of protein kinase $\mathrm{C}$ in serotonin-induced spike broadening and synaptic facilitation in sensorimotor connections of Aplysia. J Neurophysiol 68: $643-651$.

Sugita S, Baxter DA, Byrne JH. 1997. Modulation of a cAMP/protein kinase A cascade by protein kinase C in sensory neurons of Aplysia. J Neurosci 17: $7237-7244$.

Susswein AJ, Schwarz M, Feldman E. 1986. Learned changes of feeding behavior in Aplysia in response to edible and inedible foods. J Neurosci 6: $1513-1527$.

Sutton MA, Bagnall MW, Sharma SK, Shobe J, Carew TJ. 2004. Intermediate-term memory for site-specific sensitization in Aplysia is maintained by persistent activation of protein kinase C. J Neurosci 24: 3600-3609.

Sweatt JD. 2003. Mechanisms of memory. Elsevier Academic, Amsterdam.

Toullec D, Pianetti P, Coste H, Bellevergue P, Grand-Perret T, Ajakane M, Baudet V, Boissin P, Boursier E, Loriolle F, et al. 1991. The bisindolylmaleimide GF $109203 \mathrm{X}$ is a potent and selective inhibitor of protein kinase C. J Biol Chem 266: 15771-15781.

Udo H, Jin I, Kim JH, Li HL, Youn T, Hawkins RD, Kandel ER, Bailey CH. 2005. Serotonin-induced regulation of the actin network for learning-related synaptic growth requires Cdc42, N-WASP, and PAK in Aplysia sensory neurons. Neuron 45: 887-901.

Villareal G, Li Q, Cai D, Fink AE, Lim T, Bougie JK, Sossin WS, Glanzman DL. 2009. Role of protein kinase C in the induction and maintenance of serotonin-dependent enhancement of the glutamate response in isolated siphon motor neurons of Aplysia californica. J Neurosci 29: 5100-5107.

Received September 23, 2010; accepted in revised form October 13, 2010. 


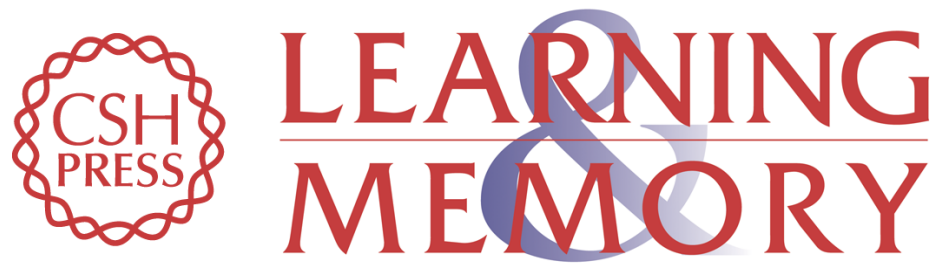

\section{PKA and PKC are required for long-term but not short-term in vivo operant memory in Aplysia}

Maximilian Michel, Charity L. Green and Lisa C. Lyons

Learn. Mem. 2011, 18:

Access the most recent version at doi:10.1101//m.2026311 Supplemental http://learnmem.cshlp.org/content/suppl/2010/12/17/18.1.19.DC1
Material

References This article cites 67 articles, 35 of which can be accessed free at: http://learnmem.cshlp.org/content/18/1/19.full.html\#ref-list-1

License

Email Alerting Receive free email alerts when new articles cite this article - sign up in the box at the Service top right corner of the article or click here. 